\title{
Proposal of Enterobacteraceae fam. nov., nom. rev. as a Substitute for the Family Name Enterobacteriaceae Rahn 1937
}

\author{
S. P. LAPAGE \\ National Collection of Type Cultures, Central Public Health Laboratory, London, NW9 5HT, England
}

In this article, the family name Enterobacteraceae nom. rev. is proposed as a substitute for the name Enterobacteriaceae, which is not formed in conformity with the Rules of the International Code of Nomenclature of Bacteria.

The Judicial Commission (6) has recently reaffirmed Opinion 15 (4) and affirmed that the family name Enterobacteriaceae Rahn 1937 (type genus, Escherichia Castellani and Chalmers 1919) has standing in nomenclature at this time and belongs on the Approved Lists of Bacterial Names (10). Nevertheless, the family name Enterobacteriaceae is not formed from the name of the type genus (Escherichia) in accordance with Rule 9 of the International Code of Nomenclature of Bacteria (8) or with Minute 9 of the 1978 Judicial Commission meeting (3), which states that the "Commission reaffirmed its policy of not permitting exceptions to the Rules on the formation of names of taxa." The proposal that the family name Enterobacteriaceae be replaced by the name Enterobacteraceae Lapage (7) has not met with universal approval $(1,2)$, and the family name Enterobacteriaceae Ewing, Farmer, and Brenner 1980 (1) ex Rahn 1937 was explicitly revived under Rule 28a of the International Code of Nomenclature of Bacteria $(1,8)$, with the recommendation that the name be retained as in Opinion 15 (4) of the Judicial Commission (whose present action [6] has established the priority of Enterobacteriaceae Rahn 1937).

In order to conform with Rule 9 of the International Code of Nomenclature of Bacteria, it still seems to me that the name Enterobacteraceae with type genus Enterobacter is to be preferred to Enterobacteriaceae; the use of Enterobacteraceae seems to be a better solution than the creation of a new family name, Escherichiaceae. Neither Enterobacteriaceae nor Enterobacteraceae Lapage 1979 were included on the Approved Lists of Bacterial Names (10), although a footnote referred to the matter as sub judice. As the former name now belongs on the Approved Lists of Bacterial Names by action of the Judicial Commission (6), the alternative name Enterobacteraceae is hereby explicitly revived with a recommendation that the Judicial Commission reconsider the original proposal of Lapage (7), so that a family name is adopted that is in conformity with Rule 9 of the International
Code of Nomenclature of Bacteria (thus closing the door to a possible multitude of future exceptions) and so that an end can be put to the uncertainty of the future validity of the name Enterobacteriaceae Rahn 1937, as expressed in the statement recently published on this subject by the Judicial Commission (6): "until and unless the Judicial Commission votes to support the proposal of Lapage, Enterobacteriaceae remains valid."

Enterobacteraceae Lapage 1979 fam. nov., nom. rev. Gram-negative, rod-shaped cells which are peritrichous when motile. Endospores are not produced. Aerobic, facultatively anaerobic. Cells grow readily on peptone media and occasionally have special growth requirements. Metabolism is respiratory and fermentative; acid is produced from glucose and other carbohydrates. Usually aerogenic, but anaerogenic groups and mutants occur. Most species are catalase positive. Oxidase negative. Cells almost always reduce nitrates to nitrites. The guanineplus-cytosine content of the deoxyribonucleic acid ranges from 39 to $59 \mathrm{~mol} \%$.

The type genus is Enterobacter Hormaeche and Edwards 1960 (nom. cons.) (5).

\section{LITERATURE CITED}

1. Ewing, W. H., J. J. Farmer III, and D. J. Brenner. 1980. Proposal of Enterobacteriaceae fam. nov., nom. rev. to replace Enterobacteriaceae Rahn 1937, nom. fam. cons. (Opinion 15, Jud. Comm. 1958), which lost standing in nomenclature on 1 January 1980 . Int. J. Syst. Bacteriol. 30:674-675.

2. Farmer, J. J., III, D. J. Brenner, and W. H. Ewing. 1980. Opposition to recent proposals which would reject the family name Enterobacteriaceae and Escherichia as its type genus. Int. J. Syst. Bacteriol. 30:660-673.

3. Holt, J. G. 1979. International Committee on Systematic Bacteriology Judicial Commission. Minutes of the Meeting, 3 September 1978, Munich, West Germany. Int. J. Syst. Bacteriol. 29:267-269.

4. Judicial Commission. 1958. Opinion 15. Conservation of the family name Enterobacteriaceae, of the name of the type genus, and designation of the type species. Int. Bull. Bacteriol. Nomencl. Taxon. 8:73-74.

5. Judicial Commission. 1963. Opinion 28. Rejection of the bacterial generic name Cloaca Castellani and Chalmers and acceptance of Enterobacter Hormaeche and Edwards as a bacterial name with type species Enterobacter clo- 
acae (Jordan) Hormaeche and Edwards. Int. Bull. Bacteriol. Nomencl. Taxon. 13:38.

6. Judicial Commission. 1981. Present standing of the family name Enterobacteriaceae Rahn 1937. Int. J. Syst. Bacteriol. 31:104.

7. Lapage, S. P. 1979. Proposal of Enterobacteraceae nom nov. as a substitute for the illegitimate but conserved name Enterobacteriaceae Rahn 1937. Request for an opinion. Int. J. Syst. Bacteriol. 29:265-266.

8. Lapage, S. P., P. H. A. Sneath, E. F. Lessel, V. B. D.
Skerman, H. P. R. Seeliger, and W. A. Clark (ed.). 1975. International code of nomenclature of bacteria. American Society for Microbiology, Washington, D.C.

9. Rahn, O. 1937. New principles for the classification of bacteria. Zentralbl. Bakteriol. Parasitenkd. Infektionskr. Hyg. Abt. 2 96:273-286.

10. Skerman, V. B. D., V. McGowan, and P. H. A. Sneath (ed.). 1980. Approved lists of bacterial names. Int. J. Syst. Bacteriol. 30:225-420. 